\title{
大規模地下街における誘導標示システムの提案と画像実験による連続性評価*
}

\section{A Sign System Designated for Busy Pedestrian Facilities and its Evaluation by Digital Image Experiments*}

大喜多梨加** • 内田 敬*** By Rika OKITA** - Takashi UCHIDA***

\section{1. はじめに}

超高齢化社会の到来、ライフスタイルの多様化が進む 中で、都市の利用者や利用目的が多様に変化している。 こうした社会変化に伴い、ターミナル地区では多様な目 的を持った人々が、円滑に移動できる必要がある。本研 究では地下街を典型とする大規模歩行者施設を対象とし、 移動の円滑化のためのサインを提案する。大規模地下街 とは複数隣接するターミナル地区を繋ぐ地下空間を指し、 特徴は管理主体の違いによる複雑な構造、利用目的に至 っては乗り継ぎ・ショッピングなど多岐にわたる。この ためにサインに一貫性がなく、利用者によって必要な情 報も異なるため満足な誘導がしにくい現状にある。また、 案内サインが存在しても商業広告に紛れてサインを容易 に発見できないことも問題である。こういった地下街の 現状から、本研究ではサインの配置を体系的に整理した サインシステムを提案する。

人が目的地一と向かう行動には大きく「学習」・「移 動」・「到着」とあり、この 3 フェーズが分断されずに 情報が繋がっているサインのことをサインシステムと呼 ぶ。この中で特に移動においては情報が分断されやすい ため本研究では移動支援に着目し、通路番号を利用して 地下空間における現在位置を把握しやすくすることを主 たる目的としている。

また、現場でのサインの視認性と発見可能性を再現す るため、そして現地の土地鑑の影響なくサインシステム を評価するため、デジタル画像を用いて室内における仮 想的なサイン評価実験を行う。

本論文ではまず、 2 章では東京で実施したサイン実地 調査と、それを人の行動に観点を置いて分類した結果の 一部を紹介する。3 章では近年のサインの動向を踏まえ

*キーワーズ:歩行者交通計画、交通情報、歩行者交通行動、

移動支援

**正員,修(工),建設技術研究所

福岡県福岡市中央区大名2-4-12 CTI福岡ビル

TEL092-714-2211

***正員,博(工), 大阪市立大学工学研究科准教授

大阪市住吉区杉本3-3-138

大阪市立大学大学院工学研究科都市基盤計画分野

TEL:06-6605-3099 FAX:06-6605-3077)
エリア・方角等の観点に基づき規則性を与えた誘導サイ ンシステムを提案する。4 章ではデジタル画像による室 内での実験、視認実験とサインシステム実験について示 す。視認実験ではサインの発見可能性を見、またサイン システム実験で用いる、意図したサインを発見できるサ イズを明らかにする。サインシステム実験ではシーケン ス画像を用い誘導標示システムの違いによる移動円滑性 の比較を行い、記号を記載した誘導標示システムの効果 をみる。

\section{2. サインの現状調査}

\section{(1) サインの分類}

近年では様々な管理主体が独自の案内サインに力を注 いでおり、誘導のための新たな要素が盛り込まれている。 ここでは東京都内の案内サインの現状を調査し、近年の サインの傾向と新たな施策を把握する。表 1 に調査概要 を示す。

近年の特徵としては、文字サイズを大きくして視認 性・判読性を上げていたり、複雑な地下構造に対応する ため、矢印の種類を多様にしている。また、矢印に戻る などの文字を入れて混乱をなくす努力もされている。

\section{表 1 調査概要}

\begin{tabular}{c|c|c|c}
\hline 調査期間 & 調査場所 & 調査内容 & 撮影枚数 \\
\hline 2005年11月15日 11月16日 & 東京都内17駅駅構内のサイン撮影 & 412 枚 \\
\hline
\end{tabular}

\section{(2) サイン内容の分類}

サインには学習を助ける「地図」、出発から到着 直前までの移動支援を行う「誘導サイン」、到着を 示す「位置サイン」と大きく 3 つる ${ }^{1)}$ 。サイン種 類の大別を行うため標示内容を大きく 4 つの要素 であらわす。

・地図 : 地下や地上の形状を把握し、予習寸るもので、 学習系のサインである。

・略図 : 構内の構造を簡略して書いてある図。

・方向 : 矢印など方向を指し示すもの。

- 文字 : 具体的名称を伝えるもの。 この 4 つを組み合わせ、16 通りで分類した。 


\section{（3）動線に基づく分類}

人の進行方向に対するサインの向きによって視認性が 変化し、それが移動に影響を与えると考え、進行方向に 対し対面か平行かで分類した。それに交差部を加え、通 路と交差部で分類し通路部-平行・通路部-対面・交差部の 3 種類とした。

\section{(4) 設置位置に関する分類}

動線に関して分類した際、設置の位置でも動線に関係 することがわかった。分類する種類は、移動中に目線上 にある「吊り型サイン」・目線高さにある「壁型サイン」・

「柱型サイン」・「自立型サイン」目線下にある「床型 サイン」の 5 種類とした。このうち「床型サイン」は誘 導する上で一般的でないため重きをおかない。

図 1に、掲示位置、内容で分類した結果を示す。ここ では、実際に収集したサインタイプをブルーで、存在す ることが予想できるものをグレーで示している。空白部 は、存在しない、またはそのような配置が適当でないと 考えられるタイプである。

\section{(5) 分類のまとめ}

旧タイプのサインの傾向としては、誘導サインは専ら 吊り看板で小さな盤面に多くの情報を盛り込もうとする ためにフォントサイズが小さいものが多かった。

新設のサインは柱全体を使うサイン(図 2)や壁を用い たサインなど、人の目線の高さに設置されたもので情報 が多く盛り込まれているものが増えてきており、日常生 活で利用し、場所に慣れている人や道に迷いにくく急ぎ たい人は天井に吊られた「吊看板」を利用し、初めて利 用する人や、道に迷いやすい人、視力の不自由な高齢者 などには柱のサインを利用させるなど、世の中の移動支 援ツールの目的明確化が進んでいる。サイン環境総体と しての視認性の向上やわかりや寸さの向上が進められて いることが調查の結果わかった。

\begin{tabular}{|c|c|c|c|c|}
\hline & & 学習 & 移動 & 到着 \\
\hline \multirow{3}{*}{ 壁 } & 通路一平行 & & & \\
\hline & 通路一対面 & & & \\
\hline & 交差部 & & & \\
\hline \multirow{3}{*}{ 吊り } & 通路一平行 & & & \\
\hline & 通路-対面 & & & \\
\hline & 交差部 & & & \\
\hline \multirow{3}{*}{ 柱 } & 通路一平行 & & & \\
\hline & 通路一対面 & & & \\
\hline & 交差部 & & & \\
\hline \multicolumn{5}{|c|}{ 収集事例にあり } \\
\hline
\end{tabular}

図 1 収集サイン画像の分類

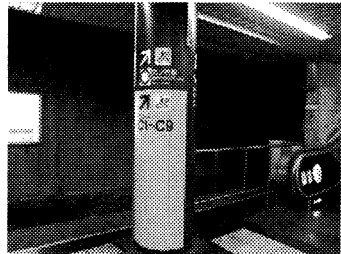

図 2 柱のサイン

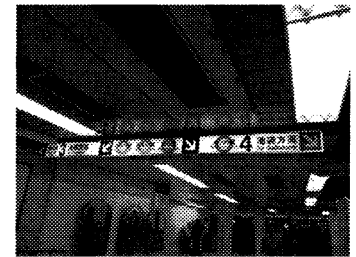

図 3 研究対象サイン
しかし、新設のスペースの大きい柱サインでも目的地 を文字で記載すると、記載できる情報に限界がでる。ま た、目印となる建物の更新の際、管理が難しい。

本研究では、地下街という比較的空間の自由度の低い 場所での移動支援について検討する。したがって、サイ ンの大きさはどこにでも置くことができる小さくて視認 性の高いものである必要がある。また、移動するのにス トレスをかけずになるべくサインを確認する時間が少な いことが望ましい。そこで、移動に必要なサインの中で も、地下街で一般的で視認性の高い「吊り型」で通路に 対面して移動している最中に確認する「通路-対面 移 動」と交わるサイン(図 3)を対象とし、誘導サインの記 載内容について提案する。

\section{3. 誘導サインシステム}

\section{（1）通路番号の命名}

本研究では地下街の誘導を円滑にするため誘導 サインの表示内容である通路出口番号について考 える。記号に規則性を与えることで目的地名と同 等・またはそれ以上の意味持たせる。そして記載す る文字数を減らすことで文字サイズを小さくする ことなく記載できる。

通路番号及び出口番号を数字や記号で規則性を もって命名することで、地下街での自分の位置や方 角を容易に把握できるものを作成することを目標 とする。

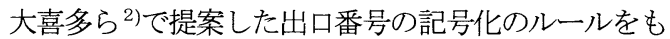
とに通路番号を作成した。現行の住居表示には街路方式 と街区方式の 2 つがあるが、本研究の通路番号は街路方 式にあたる。

通路を放射状街路網とみて付番する。具体的な手順は 図 4 に示す。記号は大分類から出口番号にいたる4桁 (例 えばA I (a)-1) である。

(1) 地下街の管理商業主体を1つのエリアとし、アルフ アベット大文字 $(\mathrm{A}, \mathrm{B}, \mathrm{C} \cdots$ ・早)で付番。

(2) エリアごとに中心を設定する。中心は何通りも設定 可能だが、条件として大きい分岐で付番が最もシン プルとなる箇所にする。

(3) (2)で設定した中心を軸に真北から時計回りにローマ 数字( I、II、III・・・)を付番する。以降、この通 


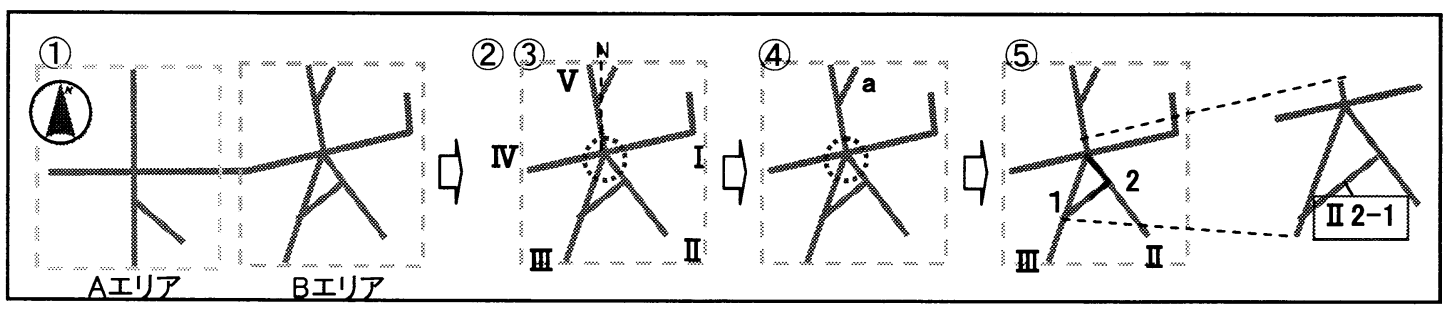

路を軸通路と呼ぶ。

(4) 軸通路から分岐した通路は中心から順にアルファベ ット小文字 $(a 、 b 、 c \cdot \cdots)$ と付番する。

（5) 分岐した通路が軸通路と軸通路を繋ぐ場合 2 通りの 付番が考えられるが、実際の移動の際に段差が少な い方や移動距離が短い方が優先して付番される。

(6) 出口の場合上記の付番に「ー(ハイフン)数字」とす る。数字は、中心から見て左側が奇数、右側が偶数 とする。

\section{(2) 誘導サイン記載項目}

本研究では3(1)で記述した、空間的に位置把握が 可能な規則性を与えた通路(出口)番号を、図 5 のよ うに誘導サインに記載する。はじめに通路(出口)番 号の記載された地図を見て目的地とする番号を覚 えて、誘導サインで番号を確認しながら向かう。も し、途中で地名が途切れても連続した番号を確認す ることにより、正確に到着することが可能となる。

通路(出口)番号の利点は、目的地名だけではわか らなかった距離感や、自分の立っている方向、複雑 な地下街の中でどの場所にいるかを特定すること ができる。また目的地名から漏れた有名でない建物 の場所にも容易に到着することが実現される。

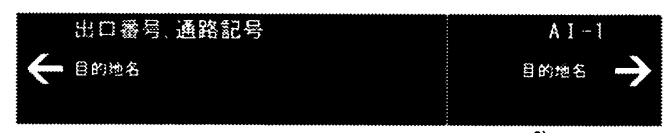

図 5 誘導サインへの記号記載例 ${ }^{2)}$

\section{4. 画像実験}

2 種類の画像実験を行なった。一つはサインが画像に おいて、どんな色や大きさのときサインだと判別できる かを知る視認実験。もう一つは 3 章で作成したサインシ ステムを評価するサインシステム実験である。

画像実験は大阪・梅田の地下街を想定対象とした。梅 田地下街の特徵は、様々な管理主体が集まり、サインに 統一性がない。また、利用者が多く、ショッピングなど 地下街自体が利用目的である場合と、駅間移動のための 通過に使用寸る場合と、様々な目的で利用している場所 である。目的が様々であるため、看板などによりサイン の視認性も低下している。

\section{（1）実験環境}

スクリーンにプロジェクターで映し出し、室内は画面 の視認性に考慮し暗くした。画面の大きさについては表 2 に示す。

・現実のスケールに近づけるためプロジェクターでスク リーンに映し出す。

・スクリーンからプロジェクターまでの距離を固定し、 スクリーンに映し出すサインの大きさを同じ条件で実験 を行う。プロジェクターの位置はスクリーンから $3 \mathrm{~m}$ の位 置に設置する。

・被験者は座り、スクリーンに近づいたり離れたりでき ない。

表 2 画像実験時の画面サイズ

\begin{tabular}{r|r|r|r}
\hline $\begin{array}{c}\text { スクリーンから } \\
\text { の距離 }\end{array}$ & $\begin{array}{c}\text { スクリーンの } \\
\text { 縦幅 }\end{array}$ & $\begin{array}{c}\text { スクリーンの } \\
\text { 横幅 }\end{array}$ & $\begin{array}{l}\text { 地面からスクリーン } \\
\text { 中心までの距離 }\end{array}$ \\
\hline $3.0 \mathrm{~m}$ & $1.1 \mathrm{~m}$ & $1.5 \mathrm{~m}$ & $1.7 \mathrm{~m}$ \\
\hline
\end{tabular}

（2） 視認実験

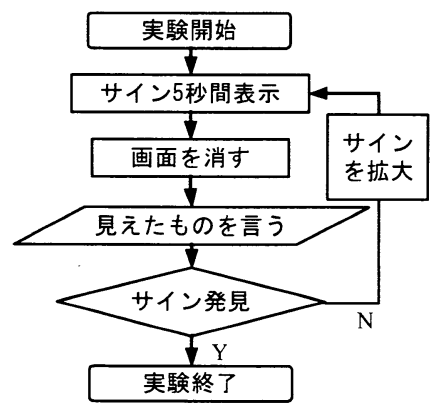

図6 視認実験の手順

実際の現場(地下街)における雑然とした状況の中での サインの発見可能性を知る実験である。

用意した歩行空間画像から案内サインを被験者に発見 させ、サインがどの程度の大きさで発見できるか、どん な色が見つけやすいか、何をサインと認識しているかを 評価する実験を行う。この実験の結果より、目的地に向 かったり、道に迷ったりした場合のサインを発見しよう としている状態で見つけられる限界の大きさを知って、 次に行うサインシステム実験で用いるべきサインの画像 サイズを決める。被験者に提示した実験の条件は次頁の 通りである。 
あなたは、地下街の通路を歩いています。

これからお見せするいくつかのシーンの中で、あなたが

目にする先にサインを見つけたら

・どんな色や形をしていたか

・どういう記号や文字が見えたか

・画面のどの位置にあったか

・いくつあったか

などの特徴を画像表示後に口頭で伝えてください。

一つの画像につき 5 秒間表示し、画像はだんだん大きく なっていきます。

なるべく目に入ったものをそのまま伝えるようにしてく ださい。

\section{(3) サインシステム実験}

実際の現場の写真を加工して出発地点から目的地 までの静止画を組み合わせた仮想空間を作成しに れをシーケンス画像と呼ぶ)を用い、サインシステム 案の違いによる経路選択性の差をみる。シーケンス 画像とは、サイン毎の画像を連続的に見せることで、 仮想的な移動を体験できるものである。実験の機器 配置は視認実験と同じである。

2007 年 1 月 21 (日)方ら 1 月 25 日(木)に実施。大阪 市立大学学生・その他併せて 28 人を被験者とした。

\section{1) シ一ケンス画像作成時の検討}

実験は地図を始めに見せ、その後仮想空間を移動する。 仮想空間作成時の条件を示寸。

\section{(a) 構造 (地図)}

仮想空間の構造は下記の条件で作成した。 (1)地図は起点 から目的地 まで 2 通りの方法で到達でき ること。

(2)その 2 通りは近道と遠回りの道であること。

(344 回分岐に当たること(単純すぎないこと)。 を条件に作成した。

(1)については、また実際の空間でも経路選択は複数存在 し、より実空間に近づけるため。(2)被験者が誘導サイン を用いて移動しているか確認する (サインの記号は近い 道を指している）ため。(3)については、無作為に移動して いれば到着するという状況を減らすため。また、地図だけ で (サインを見ないで) 移動するケースを減らすためであ る。

\section{(b) 画像}

仮想空間に用いる画像の特徽を下に示寸。

(1)サインの特徵はつかめるが、文字は判読できない画像 を用意し、サインをクリックさせること。

(2)評価の対象とするサインは吊り看板。

(3)サインは黒地に白文字で、出口番号には黄色のサイン
(1については誘導サインの内容を確認して移動してい るか、そうでないかを明確こするため。(2)につては地下 街で最も一般的である吊り看板を対象とするため。また、 後述寸るが、視認実験の結果で「サインがどこにあるかわ からない場合には遠く(画像中心付近の上の方)を探す」と いう意見が得られたため。(3)にいては(株)表示灯のデザ インを基準とし、色で評価に差をつけないためである。

\section{2) サインシステム実験の方法}

地図を始めに紙面で渡し、任意の時間確認させた後に回 収する(地図の見方については教えない)。次に被験者が画 像の中のサインを自分で発見して次の経路を決定する。そ の経路選択を繰り返し目的地に到達寸る。

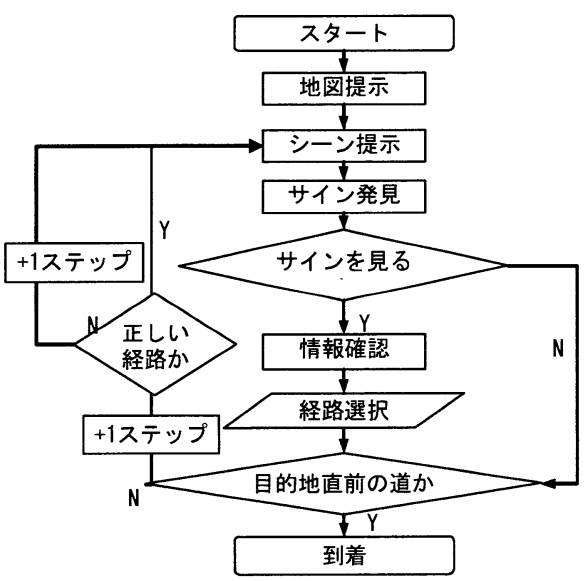

図 7 サインシステム実験の手順

\section{3）実験のパターン}

被験者 1 人に対し地図の種類が 2 種類、誘導サイ ンが 2 種類の最大 4 つのタスクを課した。

誘導サインの種類は、図 9 の日本語で目的地を最 大 3 つ記載した「文字重視実験」。図 11 の日本語で 目的地名を交通機関+1つと 3(1)のルールに基づい て作成した通路(出口) 番号を記載した「記号重視実 験」の 2 種類。

地図サインの種類は、図 8 の建物・店舗全てに名 称を記載し、ディレクトリで店の名称と場所を確認 できる「地図詳細型」、図 10 の地図に建物・店舗名 称を記載せず、ディレクトリの座標・または通路（出 口) 番号で店舗の場所を確認する「地図制約型」の 2 種類を用意した。4つのタスクの地図の構造は同じ とし、それぞれ、出発地点 2 種類と目的地 4 種類と すべて違う経路を辿るように設定した。

道の記憶や結果の偏りを減らすために試行の順番 を被験者ごとに変えた(表 3 )。 


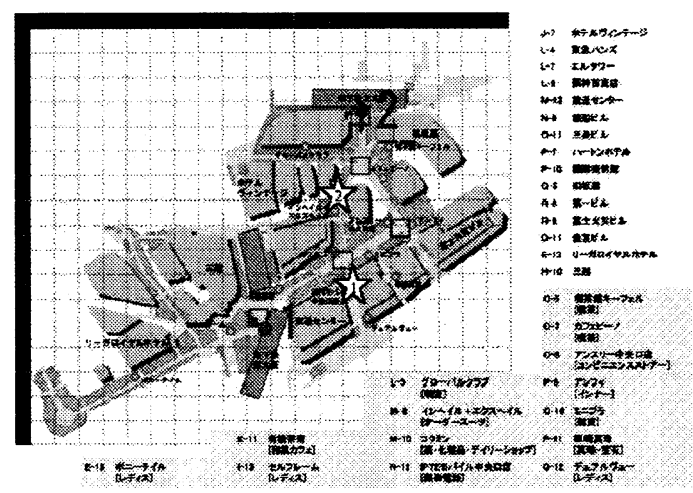

図 8 文字重視・地図詳細実験の地図

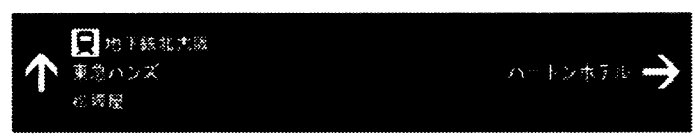

図 9 文字重視実験の誘導サイン

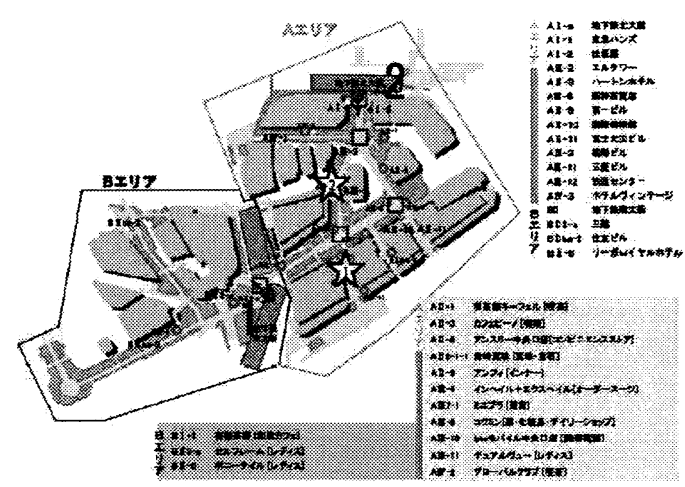

図 10 記号重視・地図制約実験の地図

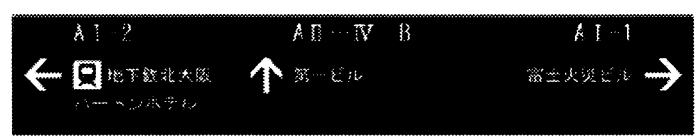

図 11 記号重視実験の誘導サイン

\begin{tabular}{|c|c|c|c|c|c|}
\hline $\begin{array}{c}\text { 実験 } \\
\text { パターン }\end{array}$ & 1回目 & 2回目 & 3回目 & 4回目 & $\begin{array}{l}\text { タイプA(文字重視 } \\
\text { +地図詳細型) }\end{array}$ \\
\hline 1 & $A-1$ & B-2 & $C-1$ & D-2 & タイ \\
\hline 2 & $A-2$ & $B-1$ & $c-2$ & $D-1$ & ＋地図詳細型 \\
\hline 3 & B-1 & $A-2$ & $D-1$ & $c-2$ & タイプC(文字重視 \\
\hline 4 & B-2 & $A-1$ & D-2 & $c-1$ & +地间 \\
\hline 5 & $A-1$ & B-2 & $D-1$ & $c-2$ & タイプD(記号重視 \\
\hline 6 & $A-2$ & B-1 & $D-2$ & $c-1$ & 十地図制 \\
\hline 7 & B-1 & $A-2$ & $c-1$ & D-2 & $A, B, C, D: タ イ フ ゚ ~$ \\
\hline 8 & $B-2$ & $A-1$ & $c-2$ & $D-1$ & 1.2：スタート地 \\
\hline
\end{tabular}

\section{5. 画像実験の結果}

\section{(1) 視認実験の結果と評価}

サインの大きさを定量的に評価するため表示した 際の画像に占めるサインの割合をみた。

$$
\text { 画面占有率 }(\%)=\frac{\text { サインの大きさ }\left(\mathrm{cm}^{2}\right)}{\text { 画像の大きさ }\left(\mathrm{cm}^{2}\right)} \times 100
$$

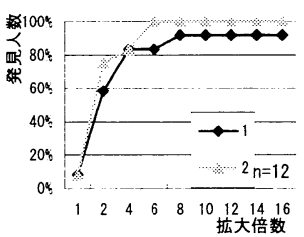

図 12(a) サイン発見人数

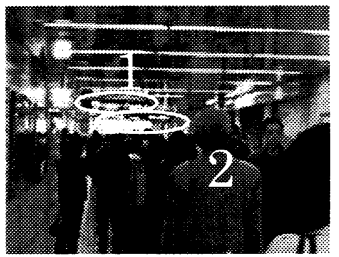

図 12 (b) 画像 3
(画像 3)

1 倍時の画面占有率は、サイン $1: 0.027 \% 、 2: 0.025 \%$ である。

図 12 は、実際の地下街のスナップ写真を提示した例で ある。サイン 1 は、黒地に白のシンプルなサイン。サイン 2 は1 よりもサイズは小さく、黒地に黄色の色のついたサ インである。図12(a)を見るとサイン 1 はサイン 2 よりも 手前にあるが発見人数は上回る結果となっている。黄色の 方が手前に見えるという意見もあったことから遠くにあ る場合黄色が発見しやすさを補助していると言える。

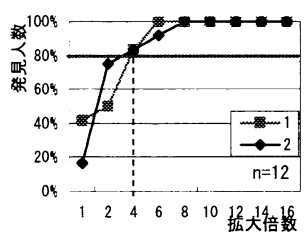

図 13(a) サイン発見人数(合成 2)

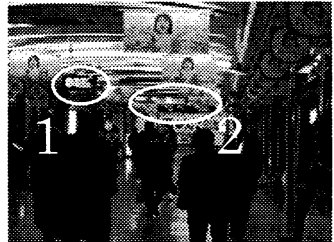

図 $13(b)$ 合成2
図 13 は地下街スナップ画像にサイン画像を合成したも のを提示した例である。サイン 1 は黒地に赤・黄・青の色 のついたサイン。サイン 2 はサイン 1 よりも大きく、黒地 に白のシンプルなサインである。

図13(b)において、1倍時の画面占有率は、1は0.050\%、 2 は $0.055 \%$ である。図 13(a)に示すように、4倍拡大で $80 \%$ 強の被験者が両サインを発見している。そこで、合成 2 の画像のサイン 1.2 の占有率の平均 $0.211 \%$ 以上の大き さのサインをサインシステム実験で用いることとした。ま た、サインを探すときの被験者の傾向として、天井付近を 探すという意見が 12 人中 9 人おり、実際歩行する際も 10 人は天井付近を見ながら移動するという意見が得られた。 
(2) サインシステム実験の結果

(a) 実験結果の分析指標

\section{ステップ数 :}

スタートから到着までに通過したシーンの数。現実

では移動距離にあたるもの。

地図確認時間・サイン確認時間 :

地図、サインを読んでいる時間。

\section{サイン使用率 :}

被験者が 1 シーンにつきサインを使用した割合。どの 程度サインに依存経路を選択したか。

サイン使用率 $=\frac{\text { サイン確認回数 }}{\text { シーン通過数 }(\text { ステプ数 })}$

また、被験者を経路の間違いやすさとサイン使用率で図 14 のように 4 タイプに分けた。

- X 軸の境界 : シーンを 3 回通過し、2 回サインを確認

した境界。サイン使用率 0.67

- $\mathrm{Y}$ 軸の境界 : 3 回に 1 回、道を間違えた境界。最小ス テップ数 $\times 1.5$
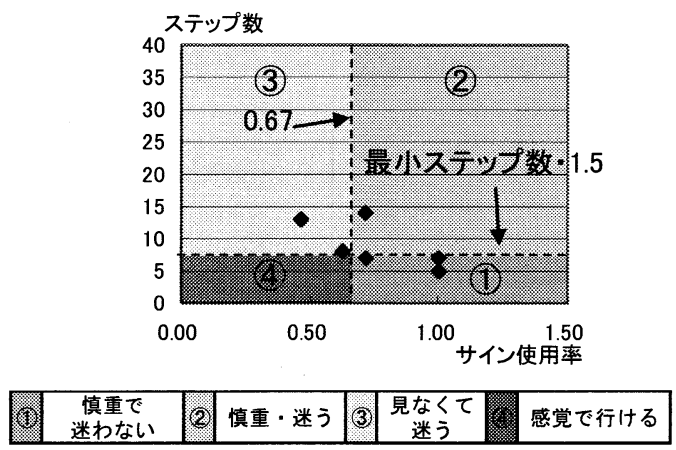

図14被験者のタイプ分け

(b) 文字重視と記号重視の比較分析

1）地図詳細型のケース

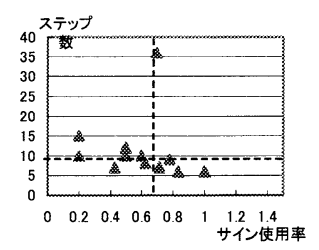

図 15 文字重視のサイン使 用率とステップ数の関係

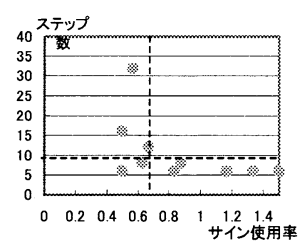

図 16 記号重視のサイン使用率 とステッフ数の関係
文字重視に比べて、記号重視では左に上がっている傾向 が見られることから、文字では何回か見逃しても見れば迷 わないが、記号は見逃したり忘れてしまうとわからなくな りステップ数が上がることを意味している。
表4 地図詳細型のデータ

\begin{tabular}{|c|c|c|c|c|c|c|}
\hline \multirow{2}{*}{\multicolumn{2}{|c|}{ サンプル数 }} & \multirow{2}{*}{ ステップ数 } & \multirow{2}{*}{$\begin{array}{c}\text { サイン確詓 } \\
\text { 時間 (秒) }\end{array}$} & \multicolumn{3}{|c|}{ 㺮図確諗時間(秒) } \\
\hline & & & & 1回目 & 人 & 2回目 \\
\hline & 8 & 6.25 & 3.15 & 47.67 & - & - \\
\hline 文 & (2) & 22.50 & 4.33 & 57.48 & 2 & 36.90 \\
\hline 重 & (3) & 10.71 & 4.87 & 40.72 & - & - \\
\hline & 1 & 7.00 & 3.00 & 26.20 & - & - \\
\hline & 全体平均 & 10.86 & 3.84 & 43.02 & & 36.90 \\
\hline & (2) & 6.00 & 4.00 & 37.42 & 1 & 11.50 \\
\hline 記 & (2) & 9.33 & 4.47 & 40.57 & - & - \\
\hline 重 & (3) & 18.67 & 4.82 & 87.62 & 2 & 29.59 \\
\hline 里 & 4 & 6.00 & 2.59 & 1.00 & - & - \\
\hline & 全体平均 & 9.43 & 3.97 & 41.65 & - & 20.54 \\
\hline
\end{tabular}

被験者の傾向は、記号重視の方が慎重な人が多い。

表 4 に地図の確認時間をみると、2 回目以降は記号重視 型の方が少ない時間で確認できている。文字重視は 2 回目 に探すときも初めから地下街の形や目印を覚え直す必要 があるが、記号重視は記号を確認寸るだけでいいため、少 ない時間で斉んだものだと考えられる。

\section{2）地図制約型のケース}

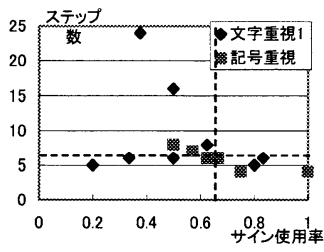

図 17 スタート地点 1

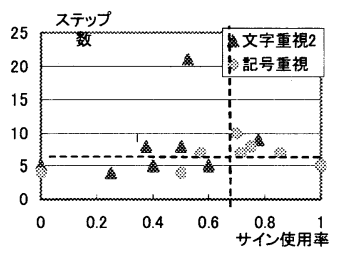

図18 スタート地点 2
文字重視と記号重視で比較するとともにサイン使用率 にばらつきがあり、いろんな被験者のタイプが実験に参加 していると考えられるが、記号重視のステップ数は境界付 近に分布していることがわかる(図 17、18)。このことよ り、記号重視で道を極端に間違える人はおらず、すぐに道 を間違えても軌道修正ができていたことがわかる。

記号重視の方が地図を見る時間 3〜15 秒長く、サイン の確認時間にほとんど違いはない(表 5、6)。

サイン使用率とステップ数の関係はサインを利用 すると経路を間違いにくくなる右下がりの関係が成 り立ち、最小ステップ数で収束する（図 17、18）。

表 5 地図制約型のデータ (スタート地点 1)

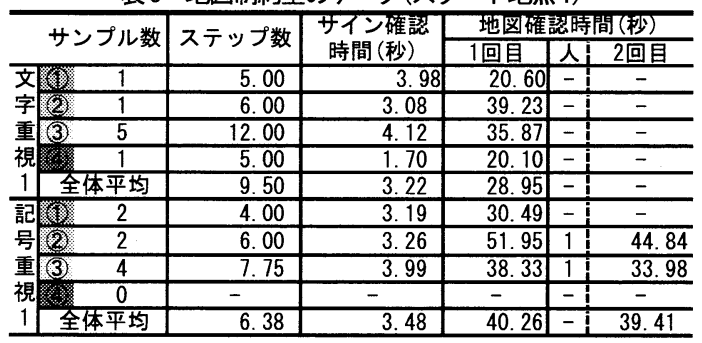


表 6 地図制約型のデータ (スタート地点 2)

\begin{tabular}{|c|c|c|c|c|c|c|}
\hline \multirow{2}{*}{\multicolumn{2}{|c|}{ サンプル数 }} & \multirow{2}{*}{ ステップ数 } & \multirow{2}{*}{$\begin{array}{c}\text { サイン確諗 } \\
\text { 時間(秒) }\end{array}$} & \multicolumn{3}{|c|}{ 地図確想時間(秒) } \\
\hline & & & & 1回目 & 人 & 2回目 \\
\hline 文 & 諘㣺 & - & - & - & - & - \\
\hline 字 & (2) & 9.00 & 4.65 & 32.91 & - & - \\
\hline 重 & (3) & 12.33 & 1.93 & 28.90 & 1 & 22.15 \\
\hline 視 & 4 & 4.75 & 1.71 & 27.92 & 1 & 37.81 \\
\hline 2 & 全体平均 & 8.13 & 2.76 & 29.91 & -1 & 29.98 \\
\hline 記 & (1) & 5.00 & 3.81 & 46.30 & - & - \\
\hline 号 & (2) & 8.00 & 4.40 & 38.90 & - & - \\
\hline 重 & (3) & 7.00 & 1.69 & 22.14 & - & - \\
\hline 視 & 2 & 4.00 & 0.97 & 32.54 & - & - \\
\hline 2 & 全体平均 & 6.50 & 2.72 & 34.97 & -1 & - \\
\hline
\end{tabular}

最後に、平均ステップ数の差に関する統計的検定 の結果を示す。「文字重視」サインの場合と「記号重 視」サインの場合について、それぞれに算出される 平均ステップ数の差の有意性について $\mathrm{t}$ 検定を行っ た。表 7 に示すように、有意水準 5\%では平均ステ ップ数の同一性は棄却されないものの、 $\mathrm{t}$ 值はかなり 大きい。例えば、片側検定で有意水準を $10 \%$ 程度ま で緩和すれば平均值の同一性が棄却される、すなわ ち平均ステップ数の差に有意性が認められる。

以上より、記号重視タイプは、地図を認識する初 めの手間はかかるが最終的な移動距離（所要ステッ プ数）は減ることがわかる。

\begin{tabular}{l} 
表 7 平均ステップ数の差に関する $\mathrm{t}$ 検定 \\
\hline \\
\hline
\end{tabular}

\section{6. まとめと今後の課題}

本研究で提案した記号重視サインシステムはステップ 数は減るがサインを何度も確訫する必要がある。しかし、 画像実験方法の使用法に慣れると通路番号にも慣れ、記号 が使いやすく感じることがわかった。記号は、漢字表記が 読めない人 (外国人など) や、地理不案内な人にも適用で きるというメリットを持つが、さらに、何度も地図を確認 する人にとっても記号重視の方が覚える内容が記号だけ で斉むため、確認する時間が減り、移動にかかる手間 (長 い間立ち止まる必要が減ることがわかった。

課題として、経路と実験タイプをそれぞれの被験 者で変えたため、結果が被験者固有の属性であるの かサインシステムのためかわかりにくく、サンプル サイズと、被験者の属性を増やす必要がある。特に、 ローマ数字などの記号表記になじみのない人や、視 力の衰えた人などにも対象を広げることが重要と考 えている。

\section{参考文献}

1）田中直人・岩田三千子:サイン環境のユニバーサルサイ ンデザイン,学芸出版,pp.12-59,2001.

2）大喜多梨加・内田敬: 大規模地下空間の誘導サインシ ステムと通路座標の提案, 日本都市計画学会関西支部 研究発表会講演概要集,pp.49-52,2005.

\section{大規模地下街における誘導標示システムの提案と画像実験による連続性評価*}

超高齢化社会の到来、ライフスタイルの多様化が進む中で、都市の利用者や利用目的が多様に変化している。 こうした社会変化に伴い、ターミナル地区では多様な人々が様々な目的を持って移動することが予想される。 大規模地下街は自分の現在位置か認識しづらい場所として着目し、一般的な誘導方法であるサインを用いて移 動の円滑化に努めることを目的とする。本研究では、サインシステム(出口番号を体系的に整理したルール)を 提案する。画像実験を用いてサインシステムを比較し、移動する際の人々の傾向を知ることができた。

\section{A Sign System Designated for Busy Pedestrian Facilities and its Evaluation by Digital Image Experiments*}

By Rika OKITA** - Takashi UCHIDA***

People walking in terminal area who have more varied purpose with various physical conditions is expected to increase. Therefore, the large-scale underground area should be focused as the difficult place for people to recognize their direction. To attain smooth walking, this study examines the Guide by Sign that is one of the basic measures for smooth walking in Large-scale underground area. The authors proposed a system concept of signs and a rule of exit numbering from the view point of sequence while walking. Also digital images are used in experiments which simulate sequential scenes in underground area. It was confirmed that the experiment in a virtual space was able to know people's tendency when he/her is usually walking. 